\title{
A new species of Hylesia Hübner (Lepidoptera, Saturniidae, Hemileucinae) from Brazilian Cerrado
}

\author{
Amabílio J. A. de Camargo \\ Embrapa Cerrados. Rodovia BR 020, km 18, Caixa Postal 08223, 73310-970 Planaltina, Distrito Federal, Brasil. \\ E-mail: amabilio@cpac.embrapa.br
}

\begin{abstract}
The genus Hylesia Hübner, [1820] has about 110 exclusively neotropical species, widely distributed from Mexico to Argentina. Here a new species (Hylesia pseudomoronensis sp. nov.) from Brazil is described. The specific name is allusive to the morphological similarity with $H$. moronensis Lemaire, 1976.

KEY WORDS. Central Brazil; Neotropical; new moth.
\end{abstract}

RESUMO. Nova espécie de Hylesia Hübner (Lepidoptera, Saturniidae, Hemileucinae) do Cerrado brasileiro. O gênero Hylesia Hübner, [1820] compreende cerca de 110 espécies exclusivamente neotropicais, com distribuição do México até a Argentina. Neste trabalho uma nova espécie (Hylesia pseudomoronensis sp. nov.) do Brasil é descrita. O nome específico se refere à similaridade morfológica da espécie descrita com H. moronensis Lemaire, 1976.

PALAVRAS-CHAVE. Brasil Central; Neotropical; nova mariposa.

The Brazilian Cerrado is a type of Savanna, being the second largest biome in the country, after Amazonia, covering about 22 percent of Brazil. However, it is among the least known of any South American biome (CAmARgo \& BeCKER 1999).

Based on data from material deposited in the Brazilian institutions and bibliography (that includes material deposited in the major European and North American museums), currently ca 1528 species of Saturniidae are known worldwide. Of these 966 occur in the Neotropical Region and 380 of them in Brazil (Balcázar-Lara \& Wolfe 1997, Camargo \& Becker 1999, Becker \& Camargo 2001, Lemaire 1976, 1978, 1980, 1988, 1996, 2002 Lemaire et al. 1999, Regier et al. 2002, Mielke \& Furtado 2005, RACHELI 2006).

About 110 species of Hylesia Hübner, [1820] are known, making it the second biggest genus of the subfamily. This group occurs only in the Neotropical region, being distributed from Mexico to Argentina. In Brazil, although there are not enough samples in most of the regions, 44 species have been recorded (Lemaire 2002). However, based on the Brazilian collections, more than 50 species of Hylesia has been considered to the country (CAMARGo \& BECKER 1999).

\section{Hylesia pseudomoronensis sp. nov.}

Figs $1-9$

Male (Figs 1-2): fore wing length $25 \mathrm{~mm}$, wingspan 48 $\mathrm{mm}$. Head and antennae dark orange; greenish eyes; thorax dorsally brownish and ventrally orange; legs, abdomen dorsally and ventrally orange; fore wing dorsally orange brown with shades of yellowish green, median area darker than remainder of the wing, ventrally yellowish brown. Hindwing dorsally brown, underside orange.

Male genitalia (Figs 6-8): similar of those of Hylesia moronensis illustrated by LEMAIRE (2002), except for the absence of the cornutus in vesica. Uncus simple, sclerotized and robust, downcurved posteriorly. Valvae large, bilobed; inner sclerotized spine long arising near apex; sacculus prominent not totally fused with valvae; juxta esclerotized; aedeagus without thorn; vesica and bulbus ejaculatorius without cornutus or any other similar structure.

Female (Figs 3-4): Sexual dimorphism strongly developed. Fore wing length $37 \mathrm{~mm}$, wingspan $60 \mathrm{~mm}$. Head and antennae dark; greenish eyes; thorax dorsally dark and ventrally brownish red; legs and abdomen dorsally and ventrally brownish red; the last abdominal segment with pleated aspect (Fig. 5); anal tuft yellow; dorsally, fore wing is dark with external margin darker than median area. Hindwing is also dark. Ventrally, both fore and hindwing are gray.

Female genitalia (Fig. 9): corpus bursae long and without signum; ductus bursae, anterior and posterior apophyses, lamellae postvaginalis and antevaginalis esclerotized; ductus seminalis arising from base of bursae.

Holotype male: BrazIL, Minas Gerais: I raí de Minas (1843'S 4730’W, 950 m), 16.IX.1993, Camargo leg., (CPAC 11400). Paratypes: BraSIL, Goiás: Catalão, 17ำ2'S 47ํ2'W, 920 m), 2 female, 23-31.X.2001, Camargo leg., (CPAC 18337 and CPAC 18338). The specimens are deposited in the Embrapa Cerrados' Collection, Planaltina, Distrito Federal, Brazil. 

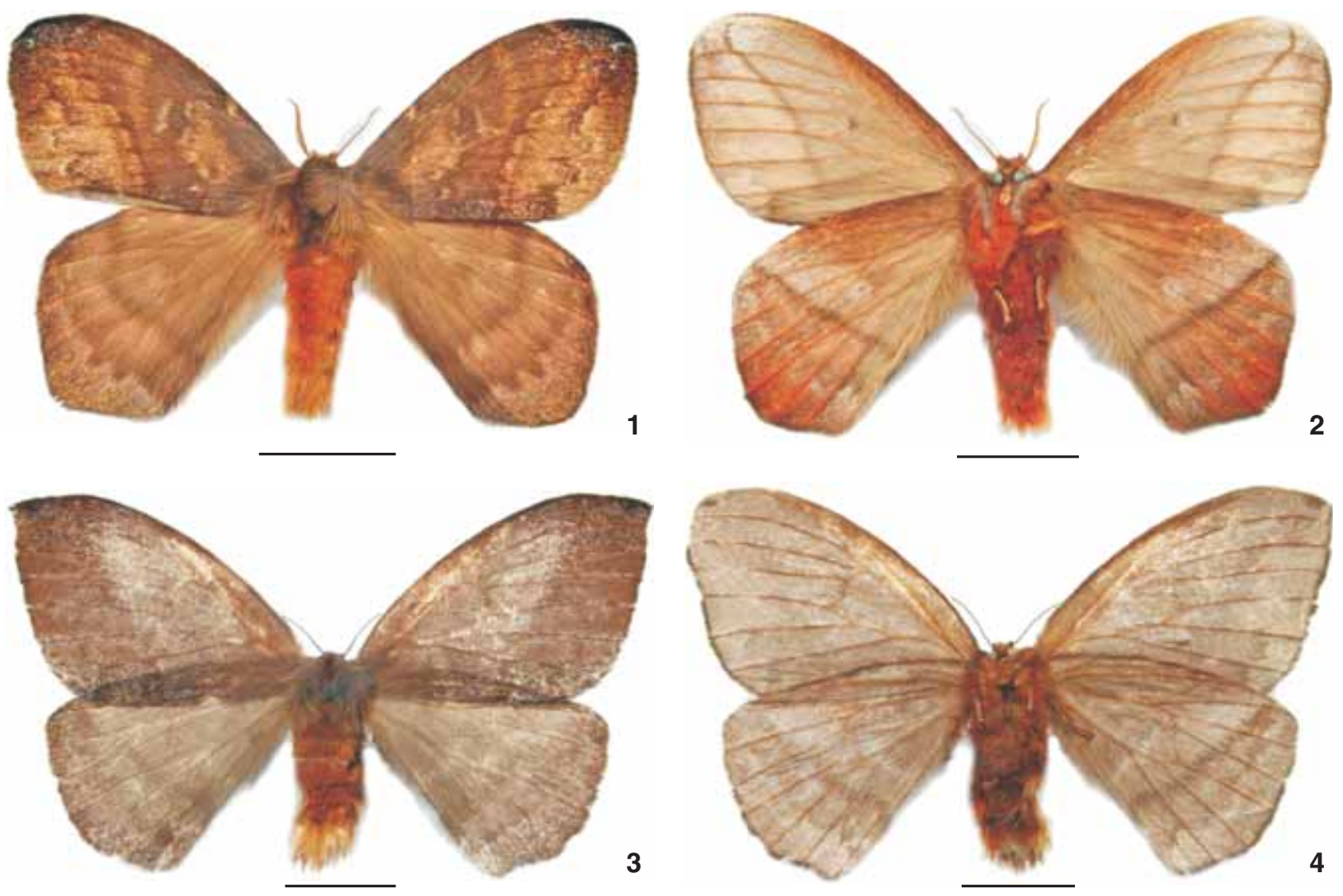

Figures 1-4. Hylesia pseudomoronensis sp. nov.: (1-2) male holotype: (1) dorsal view; (2) ventral view; (3-4) female: (3) dorsal view; (4) ventral view. Scale bar: $1.0 \mathrm{~cm}$.

Remarks: This species resembles Hylesia moronensis Lemaire, 1976 and Hylesia aeneides (Druce, 1897). However, it differs from $\mathrm{H}$. moronensis by orange coloration and absence of the cornutus in vesica. Differs from $\mathrm{H}$. aeneides by the absence of the long process arising from the inner margin of the saccuIus. Besides, the geographical distribution of both doesn't include Brazil, not coinciding with the one of the described species. $\mathrm{H}$. aeneides is distributed in Central America, north and west of South America (Costa Rica, Panama, French Guiana, Venezuela, Colombia, Ecuador, Peru and Bolivia), while H. moronenesis occurs in Venezuela, Ecuador and Peru (Lemaire 2002). The male sample was collected in Gallery Forest before the beginning of the rainy period in the Cerrado Region. Because they presented a mild environment during dry season, Gallery Forests form shelters and dispersion way to certain groups of typical fauna from damper environments (BRown 2000, CAmARGo 2001). The females were captured in typical Cerrado vegetation areas during the rainy season. The specimens were collected with a light trap (white sheet illuminated with a 250-W mercury-vapor bulb).

Revista Brasileira de Zoologia 24 (1): 199-202, março 2007

\section{ACKNOWLEDGEMENTS}

The author is most grateful to Embrapa Cerrados technicians Mr. Wellington Cavalcanti, for producing the line drawings and Mr. Jânio Fonseca Silva for helping with specimens preparation. I also thank Karen Schmidt, Willian R. F. Camargo and Nícholas F. Camargo for suggestions on the manuscript. To PROBIO/MMA and JICA (Japanese International Cooperation Agency) for the financial support.

\section{REFERENCES}

Becker, V.O. \& A.J.A. Camargo. 2001. Three new species of Saturniidae (Lepidoptera) from Central Brazil. Revista Brasileira de Zoologia 18 (1): 163-170.

Brown, K.S. 2000. Insetos indicadores da história, composição, diversidade e integridade de Matas Ciliares, p. 223-232. In: R.R. Rodrigues \& H.F. LeITÃo FILHO (Eds). Matas ciliares: conservação e recuperação. São Paulo, EDUSP, XV+320p.

BalcÁZAR-LARA L.M.A. \& K.L. Wolfe. 1997. Cladistics of the Ceratocampinae (Lepidoptera: Saturniidae). Tropical Lepidop- 

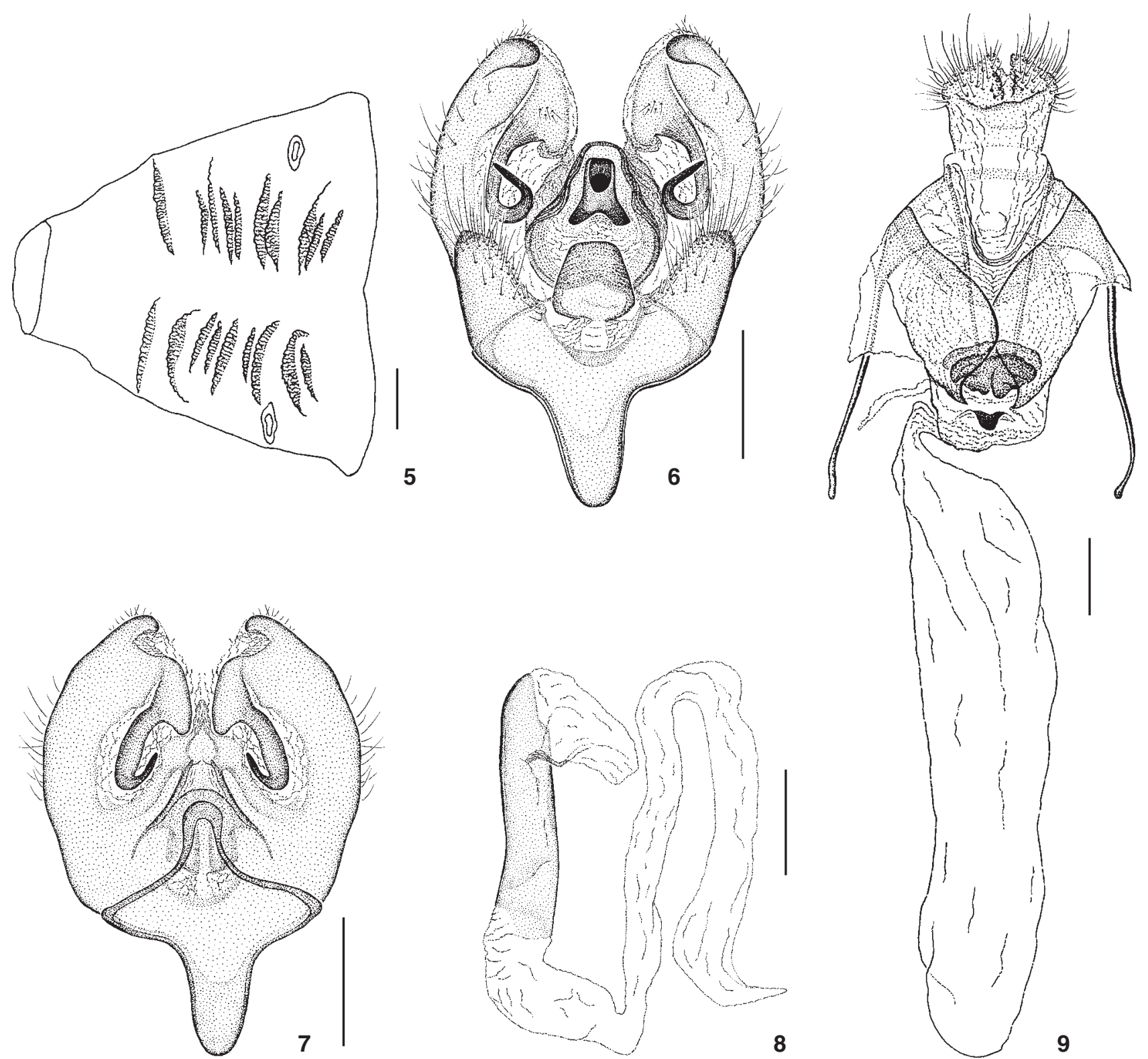

8

9

Figures 5-9. Hylesia pseudomoronensis: (5) ventral view of last abdominal segment of female; (6-7) male genitalia views: (6) ventral; (7) dorsal; (8) aedeagus, lateral view; (9) female genitalia, ventral view. scale bar: $1.0 \mathrm{~mm}$.

tera 8 (Suppl. 2): 1-53.

CAMARGO, A.J.A. de. 2001. Importância das matas de galeria para a conservação de lepidópteros do Cerrado, p. 607-634. In: J.F. Ribeiro; C.E.L. Fonseca \& J.C. Sousa-Silva (Eds). Cerrado: caracterização e recuperação de Matas de Galeria. Planaltina, Embrapa Cerrados, XVI+899p.

Camargo, A.J.A. \& V.O. Becker. 1999. Saturniidae (Lepidoptera) from the Brazilian Cerrado: Composition and Biogeographic Relationships. Biotropica 31 (4): 696-705.
Lemaire, C. 1976. Biogeographie des Attacidae de l'Equateur, p. 223-306. In: H. Descimon (Ed.). Biogeographie et evolution en Amerique Tropicale. Publications du Laboratoire de Zoologie de l'Ecole Superieure, n. 9. Paris.y

LemAire, C.1978. Les Attacidae Américains (= Saturniidae). Attacinae. Édition C. Lemaire, Neuilly-sur-Seine, 238p.

Lemaire, C. 1980. Les Attacidae Américains (= Saturniidae).

Arsenurinae Édition C. Lemaire, Neuilly-sur-Seine, 199p. LemaIRE, C. 1988. LesAttacidaeAméricains(=Attacidae). Cera-

Revista Brasileira de Zoologia 24 (1): 199-202, março 2007 
tocampinae. San José, Museo Nacional de Costa Rica. 480p. Lemaire, C. 1996. Checklist: part 4B. Saturniidae. Atlas of Tropical Lepidoptera 117: 28-49.

Lemaire, C. 2002. The Attacidae of America. Hemileucinae.

Part A. Goecke \& Evers, Keltern, Germany, 688pp.

Lemaire, C.; N. TANGerini \& O.H.H. Mielke. 1999. A new genus of Ceratocampinaefrom Brazil (Lepidoptera: Saturniidae). Tropical Lepidoptera 10 (1): 31-33.

Mielke, C.G.C. \& E. Furtado. 2005. Paradaemonia balsasensis sp. nov. da Serra do Penitente, Balsas, Maranhão, Brasil
(Lepidoptera, Saturniidae, Arsenurinae). Revista Brasileira de Zoologia 22 (3): 653-655.

RACHELI, L. 2006. List of the Arsenurinae of Peru with taxonomic notes on Titaea raveni (Johnson \& Michener, 1948) stat. rev. and Parademonia castanea (Rothschild, 1907) stat. rev. (Lepidoptera, Saturniidae). Galathea 22 (1): 41-47.

Regier, J.C.; C. Mitter; R.S. Peigler \& T. P. Friedlander. 2002. Monophyly, composition, and relationships within Saturniidae (Lepidoptera: Saturniidae): evidence from two nuclear genes. Insect Systematics and Evolution 33: 9-21.

Received in 04.X.2006; accepted in 07.III.2007. 